\title{
Veiligheid, interne controle en assurance-services
}

\section{Oscar van Leeuwen}

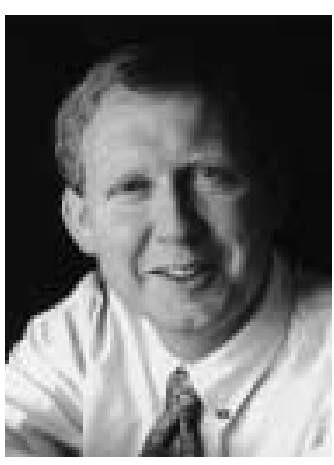

Het afgelopen jaar is de Nederlandse samenleving opgeschrikt door een aantal rampen. De ramp op 13 mei 2000 in

Enschede met de ontplofte vuurwerkopslagplaats van SE Fireworks en de brand op oudejaarsavond in de discotheek in Volendam zijn hiervan trieste voorbeelden. Uit

later onderzoek van deze rampen bleek dat veiligheidsvoorschriften niet zijn nageleefd. Ik vraag mij bij het bekijken van de beelden van dergelijke rampen vaak af: was dit nu echt nodig?

Collega Wallage schreef in zijn column in het aprilnummer van $\mathrm{MAB}$ dat er wat hem betreft 'te veel gedoogd wordt'.

Interessant om vast te stellen is dat er kort na het ongeluk in het algemeen weinig mededogen meer is. Nadat duidelijk is geworden dat er met de veiligheid iets vreselijk mis is gegaan, wordt vaak direct een commissie ingesteld die gaat onderzoeken wat er precies is gebeurd. De pers richt zich intussen op de vraag of de hulpverlening snel genoeg op gang kwam. Nadat dit stadium is gepasseerd en het rapport van de commissie eraan komt, gaan de discussies vervolgens helaas niet over hoe dit nu allemaal te voorkomen zou zijn geweest. Want wat de pers en de politiek betreft is één ding zeker: 'Barbertje moet hangen'. De vraag is alleen maar wie Barbertje is en hoeveel Barbertjes er zijn en of Barbertje al of niet de

Prof. Dr. O.C. van Leeuwen RA is werkzaam als hoogleraar Bestuurlijke Informatieverzorging Administratieve Organisatie aan de Vrije Universiteit van Amsterdam. Daarnaast is hij werkzaam bij KPMG Consulting. eer aan zichzelf wil houden. Zo was een van de koppen op de voorpagina van Trouw van 20 maart 2001 'Raad Enschede laat Mans ongemoeid'. Verder lezend blijkt dat op basis van het rapport van de Commissie Oosting in het kader van de ramp met de ontplofte vuurwerkopslagplaats van SE Fireworks in Enschede een discussie is gevoerd over de positie van burgemeester J. Mans. De burgemeester mag volgens dit krantenbericht aanblijven van de gemeenteraad van Enschede. Eerder al waren de wethouders Koopmans (VVD) en Buursink (PvdA) opgestapt.

De vraag of dit nu allemaal niet te voorkomen is, zal inmiddels bij de meeste bestuurders van gemeenten ook wel opgekomen zijn. Dit lijkt mijlos van de vreselijke gevolgen van dergelijke rampen - ook vanuit het eigen belang van bestuurders en toezichthouders geredeneerd een belangrijke vraag. Als het te voorkomen is hoeven zij immers niet af te treden. Het is voor hen derhalve van groot belang vooraf preventieve maatregelen te nemen. Dat is beter dan achteraf de put te dempen als het kalf verdronken is. Dat betekent dat er informatie beschikbaar zal moeten komen over de vraag of de veiligheidsregels wel of niet zijn overtreden.

Dergelijke vraagstukken liggen primair op het terrein van de interne controle of internal control. De feilbaarheid van mensen en apparatuur maakt het noodzakelijk dat controle wordt uitgeoefend op de uitkomsten van hetgeen door mensen en apparatuur wordt verricht (Starreveld, De Mare en Joels, Bestuurlijke informatieverzorging deel 1, 1994, p. 261). Deze controle kan op drie manieren plaatsvinden. Het is mogelijk jezelf te controleren (zelfcontrole), een externe persoon te laten controleren of het goed is gegaan (externe controle) of interne controle te laten uitoefenen. Ook internationaal gezien is dit reeds lang bekend. In het algemeen blijkt dat de oorzaak van het falen veel- 
al gelegen is in het niet opvolgen van wet- of regelgeving. Het internationaal meest toonaangevende rapport over internal control (Coso) spreekt in dit verband over het vaststellen van 'compliance with applicable rules and regulations'.

In de genoemde rampgevallen lijken de systemen van internal control waarmee toezicht op de regelgeving kan worden uitgeoefend niet goed te zijn ingericht of te falen. Er lijkt hier eerder sprake te zijn van het topje van de ijsberg dan van incidenten. Naar mijn mening ${ }^{l}$ is een van de oorzaken hiervoor een onderschatting door bestuurders van de risico's die er worden gelopen bij het niet naleven van de regels, en onvoldoende bekendheid met de methoden en technieken van interne controle om tot een adequaat toezicht op de regelgeving te komen. Ik zou daarom willen pleiten voor een verplichte cursus interne controle voor bestuurders en toezichthouders, om hen zo goed mogelijk in staat te stellen op de veiligheid van Nederland te letten.

Een andere vraag die zich naar aanleiding van dergelijke miskleunen voordoet, is hoe de auditbranche inspeelt op dit soort ontwikkelingen. Een bestuurder die niet helemaal zeker is van zijn zaak zou immers aan een accountant kunnen vragen een 'veiligheidsverklaring' af te geven. Naar mijn mening zou deze 'assurance-service' met kracht door de accountantsbureaus moeten worden ontwikkeld en in de markt gezet, zodat wij allemaal rustiger kunnen slapen.

NOOT

$1 \mathrm{lk}$ deel overigens de mening van collega Wallage (column in het aprilnummer van $M A B$ ) dat er te veel wordt gedoogd. Van het Volendamse café Het Hemeltje was immers bekend dat er niet was voldaan aan de veiligheidsvoorschriften van de brandweer. 